\title{
ANALISIS DEBT TO EQUITY RATIO, EARNING PER SHARE, RETURN ON ASSETS DAN PRICE EARNING RATIO TERHADAP HARGA SAHAM
}

\author{
Fajar Fajrian"1, Riyandi Nur Sumawidjaja ${ }^{2}$ \\ ${ }^{1,2}$ Program Studi Manajemen, STIE Indonesia Membangun, Bandung, Indonesia \\ Fajarfajrian13@gmail.com ${ }^{1}$,riyandinursumawidjaja@gmail.com²
}

\begin{abstract}
This study aims to analyze the effect of Debt to Equity Ratio (DER), Earning Per Share (EPS), Return on Assets (ROA) on Stock Prices through Price Earning Ratio (PER). This research uses quantitative methods. The secondary data type is sourced from the published financial statements of the Indonesia Stock Exchange. Data analysis using path analysis. The results showed: (1) Debt to Equity Ratio had no significant effect on Price Earning Ratio; (2) Earning per Share does not significantly influence Price Earning Ratio; (3) Return on Assets has a significant influence on Price Earning Ratio; (4) Debt to Equity Ratio has no significant effect on stock prices; (5) Earning per Share has a significant influence on Prices; (6) Return on Assets has no significant effect on stock prices; (7) Price Earning Ratio has no significant effect on stock prices; (8) Debt to Equity Ratio, Earning per Share, and Return on Assets simultaneously have a significant effect on Price Earning Ratio; (9) Debt to Equity Ratio, Earning per Share, Return on Assets and Price Earning Ratio simultaneously have a significant effect on Stock Prices; (10) Debt to Equity Ratio, Earning per Share and Return on Assets simultaneously have a significant effect on Price Earning Ratio.
\end{abstract}

Keywords: debt to equity ratio; earning per share; return on assets; price earning ratio; share prices

Abstrak

Penelitian ini bertujuan untuk menganalisis pengaruh Debt to Equity Ratio (DER), Earning Per Share (EPS), Return on Assets (ROA) terhadap Harga Saham melalui Price Earning Ratio. Penelitian ini menggunakan metode kuantitatif. Jenis data sekunder bersumber dari laporan keuangan Bursa Efek Indonesia yang telah dipublikasikan. Analisis data menggunakan analisis jalur (path analysis). Hasil penelitian menunjukkan (1) Debt to Equity Ratio tidak berpengaruh signifikan terhadap Price Earning Ratio; (2) Earning per Share tidak memberikan pengaruh secara signifikan terhadap Price Earning Ratio; (3) Return on Assets memberikan pengaruh signifikan terhadap Price Earning Ratio; (4) Debt to Equity Ratio tidak berpengaruh signifikan terhadap Harga Saham; (5) Earning per Share memberikan pengaruh signifikan terhadap Harga; (6) Return on Assets tidak memberikan pengaruh signifikan terhadap Harga Saham; (7) Price Earning Ratio tidak berpengaruh signifikan terhadap Harga Saham; (8) Debt to Equity Ratio, Earning per Share, dan Return on Assets secara simultan berpengaruh signifikan terhadap Price Earning Ratio; (9) Debt to Equity Ratio, Earning per Share, Return on Assets dan Price Earning Ratio secara simultan berpengaruh signifikan terhadap Harga Saham; (10) Debt to Equity Ratio, Earning per Share dan Return on Assets secara simultan berpengaruh signifikan terhadap Price Earning Ratio.

Kata Kunci: debt to equity ratio; earning per share; return on assets; price earning ratio; harga saham 


\section{PENDAHULUAN}

Sektor industri dalam pembangunan ekonomi di berbagai negara sangat penting karena sektor industri memiliki beberapa keunggulan dalam hal akselerasi pembangunan, diantaranya memberikan kontribusi bagi penyerapan tenaga kerja dan mampu menciptakan value added yang lebih tinggi pada berbagai komoditas yang dihasilkan. Salah satu sektor industri yang memberikan kontribusi besar bagi ekonomi nasional adalah industri hasil tembakau.

Tembakau merupakan salah satu komoditas perdagangan penting di dunia termasuk Indonesia. Produk tembakau utama yang diperdagangkan adalah daun tembakau dan rokok, merupakan produk bernilai tinggi, sehingga bagi beberapa negara termasuk Indonesia berperan dalam perekonomian nasional sebagai salah satu sumber devisa, sumber penerimaan pemerintah dan pajak (cukai), sumber pendapatan petani dan lapangan kerja bagi masyarakat (Rachmat, M. \& Nuryanti, S., 2009).

Dilihat dari sisi ekonomi, rokok merupakan salah satu industri yang sangat menjanjikan, diperkirakan perusahaan rokok telah menyerap 6,1 juta tenaga kerja. Kementerian Keuangan juga mencatat bahwa penerimaan cukai rokok sebesar Rp 8,1 triliun pada dua bulan awal 2016. Sementara penerimaan cukai rokok pada APBN-P 2016 dipatok sebesar Rp 141,7 triliun. Angka ini lebih tinggi $\mathrm{Rp}$ 1,9 triliun dari target APBN 2016 sebesar Rp 139,8 triliun. Besarnya angka pendapatan rokok ini, tidak lepas dari banyaknya jumlah perokok di Indonesia yang mencapai hingga $66 \%$ dari total penduduknya. Jumlah ini membuat Indonesia menjadi negara dengan perokok terbesar nomor 1 di dunia, diikuti Rusia sebesar 60 persen dari jumlah penduduknya.

Produk tembakau di Indonesia menarik minat para investor untuk investasi di pasar modal dengan membeli sejumlah saham saat ini dengan harapan memperoleh keuntungan dari kenaikan harga saham ataupun sejumlah dividen di masa yang akan datang, sebagai imbalan atas waktu dan risiko yang terkait dengan investasi tersebut (Tandelilin, E., 2010). Penentuan harga saham dapat berdasarkan harga penutupan (closing price), yang biasanya digunakan untuk memprediksi harga saham pada periode berikutnya (Anoraga, 2008; Rusdin, 2008).

Gambar 1 menunjukkan harga saham closing price pada perusahaan manufaktur sub sektor rokok yang terdaftar di BEI periode 2013-2017.

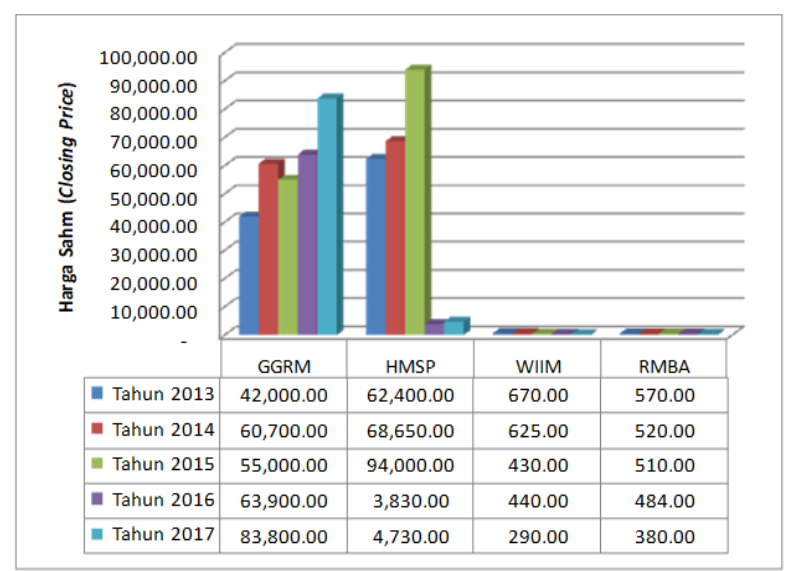

Gambar 1. Harga Saham pada Perusahaan Manufaktur Sub Sektor Rokok Sumber : IDX Statistik pada BEI 2013-2017 (data diolah)

Gambar 1 menunjukkan harga saham closing price PT Gudang Garam, Tbk. (GGRM) mengalami kenaikan signifikan selama periode 2013-2017, sedangkan PT Hanjaya Mandala Sampoerna Tbk. (HMSP) mengalami penurunan pada periode 20152016. Berbeda dengan PT Wismilak Inti Timur, Tbk. (WIIM) dan PT Bentoel Internasional Investama Tbk. (RMBA) dimana harga saham selama periode 2013-2017 terus menerus menurun. Fluktuasi harga saham di pasar modal dapat dipengaruhi oleh faktor eksternal maupun faktor internal perusahaan (Brigham \& Houston, 2010). Faktor-faktor tersebut adalah rasio laba terhadap harga per lembar saham atau Price Earning Ratio (PER), laba per lembar saham atau Earning Per Share (EPS), tingkat bunga bebas risiko yang diukur dari tingkat bunga deposito pemerintah dan tingkat kepastian operasi perusahaan. (Sartono, A., 2010). Faktor lainnya adalah Debt to Equity Ratio (DER) dan Profitabilitas yang diproksikan dengan Return on Asset dan Return on Equity (ROE) (Brigham \& Houston, 2010).

Price Earning Ratio (PER) berhubungan dengan harga saham, karena fluktuasi harga saham tergantung pada tingkat optimisme pasar (Sinaga, B, 2014). PER yang 
semakin tinggi menunjukkan semakin optimis pasar dalam memandang prospek masa depan perekonomian. Sebaliknya PER yang semakin rendah maka pasar semakin cemas atau pesimis. Earning per Share (EPS), merupakan jumlah pendapatan yang diperoleh dalam satu periode untuk setiap lembar saham yang beredar. EPS yang tinggi, akan menarik investor untuk membeli saham sehingga harga saham menjadi tinggi. Penelitian Febrianto, A.D. \& Kartawinata, B.R. (2014) yang menunjukkan bahwa EPS tidak berpengaruh positif terhadap harga saham.

Debt to Equity Ratio (DER) merupakan rasio yang berpengaruh terhadap harga saham. DER sebagai ukuran yang memperlihatkan besarnya jaminan tersedia bagi kreditor yang diberikan oleh pemilik perusahaan. Penelitian Nurfadilah (2011) menunjukkan DER berpengaruh signifikan terhadap harga saham, sedangkan penelitian Safitri, A.L. (2013) bahwa DER tidak berpengaruh signifikan terhadap harga saham.

Profitabilitas yang diproksikan dengan Return on Asset mempunyai arti penting bagi perusahaan di dalam mempertahankan kelangsungan hidupnya untuk jangka panjang karena seorang investor atau pemegang saham badan usaha berkepentingan atas penghasilan saat ini dan yang diharapkan di masa yang akan datang, kestabilan penghasilan dan keterkaitan dengan penghasilan perusahaan yang lain. Return on Asset mengukur kemampuan perusahaan menghasilkan keuntungan pada masa lampau untuk diproyeksikan di masa yang akan datang (Brigham \& Houston, 2011). Seperti penelitian Zuliarni, S (2012) yang bahwa ROA berpengaruh signifikan positif terhadap harga saham.

\section{KAJIAN PUSTAKA}

Harga saham terbentuk melalui mekanisme permintaan dan penawaran di pasar modal. Apabila suatu saham mengalami kelebihan permintaan, maka harga saham cenderung naik. Sebaliknya, apabila kelebihan penawaran maka harga saham cenderung turun (Sartono, 2010). Harga saham didefinisikan sebagai: (1) Harga atau nilai uang yang bersedia dikeluarkan untuk memperoleh atas suatu saham (Widoatmojo, 2012); (2) Harga saham menentukan kekayaan pemegang saham. Maksimalisasi kekayaan pemegang saham diterjemahkan menjadi maksimalkan harga saham perusahaan. Harga saham pada satu waktu tertentu akan bergantung pada arus kas yang diharapkan diterima di masa depan oleh investor "rata-rata" jika investor membeli saham (Brigham \& Houston, 2010). Fluktuasi harga saham dipengaruhi oleh faktor eksternal dan internal perusahaan (Brigham \& Houston, 2010). (1) Faktor internal, diantaranya: Pengumuman laporan keuangan perusahaan, seperti peramalan laba sebelum akhir tahun fiskal dan setelah akhir tahun fiskal, earning per share (EPS), dividen per shere (DPS), Price Earning Ratio (PER), Net Profit Margin (NPM), Return On Assets (ROA) dan lain-lain. (2) Faktor eksternal, seperti pengumuman pemerintah tentang perubahan suku bunga tabungan dan deposito kurs valuta asing, inflasi, serta berbagai regulasi dan regulasi ekonomi; Pengumuman hukum seperti tuntutan terhadap perusahaan atau terhadap manajernya; serta pengumuman industri sekuritas, seperti laporan pertemuan tahunan insider trading, volume atau harga saham perdagangan pembatasan atau penundaan trading.

Price Earning Ratio (PER), didefinisikan sebagai (1) Rasio harga per saham terhadap laba per saham menunjukkan jumlah yang dibayarkan oleh investor untuk setiap dolar laba yang dilaporkan (Brigham \& Houston, 2010); (2) Perbandingan antara market price pershare (harga pasar per lembar saham) dengan earning pershare (laba perlembar saham) terhadap kenaikan pertumbuhan laba yang diharapkan juga akan mengalami kenaikan (Fahmi, 2013); (3) Rasio harga saham terhadap Price Earning Ratio lain yang menunjukkan seberapa besar pemodal menilai harga saham terhadap kelipatan dari Earnings (Jogiyanto, 2013).

Price Earning Ratio (PER) berkaitan erat dengan harga saham. Semakin besar PER suatu saham maka menyatakan saham tersebut akan semakin mahal terhadap pendapatan bersih per saham. Jika dikatakan suatu saham mempunyai PER 10 kali, berarti harga saham tersebut 10 kali lipat terhadap EPSnya. Saham yang memiliki PER yang semakin kecil bagi pemodal akan semakin bagus, karena saham 
tersebut memiliki harga yang semakin murah. PER merupakan salah satu aspek untuk mengukur kinerja harga saham. Secara matematis, rumus PER sebagai berikut:

$$
\text { Price Earning Ratio }=\frac{\text { Price Stock }}{\text { Earning per Share }}
$$

(Tandelilin, E., 2010)

$$
\text { Penelitian Mujati, Y. \& Dzulqodah, M. }
$$

(2016) bahwa Price Earning Ratio
berpengaruh terhadap harga saham, sedangkan Amanda, A. dkk (2012) menyatakan Price Earning Ratio tidak berpengaruh terhadap harga saham

Debt to Equity Ratio (DER) merupakan rasio yang berpengaruh terhadap harga saham. DER sebagai ukuran yang memperlihatkan besarnya jaminan tersedia bagi kreditor yang diberikan oleh pemilik perusahaan. DER merupakan rasio yang digunakan untuk menilai hutang dengan ekuitas, dihitung dengan cara membandingkan seluruh hutang, termasuk hutang lancar dengan seluruh ekuitas. Semakin tinggi DER menunjukkan komposisi total hutang (jangka pendek dan jangka panjang) semakin besar dibanding dengan total modal sendiri, sehingga berdampak terhadap semakin besarnya beban perusahaan terhadap pihak luar (Kasmir, 2014). DER dinyatakan dengan rumus sebagai berikut:

Debt to Equity Ratio $=\frac{\text { Debt }}{\text { Equity }} \quad($ Kasmir, 2014)

Penelitian Mujati, Y. \& Dzulqodah, M. (2016) menyatakan bahwa Debt to Equity Ratio berpengaruh terhadap Harga Saham. Demikian pula dengan penelitian Rhidho, R. \& Prabawa, S.A (2012); Arisona, V.F. (2013) menjelaskan bahwa Debt to Equity Ratio tidak berpengaruh signifikan terhadap Price Earning Ratio sedangkan Mandasari, P. (2016) menunjukkan bahwa Debt to Equity Ratio berpengaruh positif terhadap Price Earning Ratio.

$\begin{array}{ccc}\text { Earning } & \text { Per Share (EPS) merupakan } \\ \text { rasio untuk mengukur keberhasilan }\end{array}$ manajemen dalam mencapai keuntungan bagi pemegang saham. Semakin tinggi nilai EPS tentu saja menggembirakan pemegang saham karena semakin besar laba yang disediakan untuk pemegang saham (Kasmir, 2012). EPS dirumuskan sebagai berikut:

Earning Per Share $=\frac{\text { Laba Bersih Setelah Bunga dan Pajak }}{\text { Jumlah Saham Beredar }}$ (Kasmir, 2012)

Penelitian Husaini, A. (2012), Tamuntuan, U. (2015) dan Ratih, D. dkk (2013) bahwa Earning per Share berpengaruh terhadap harga saham sedangkan penelitian yang dilakukan oleh Febrianto, A.D. \& Kartawinata, B.R. (2015) menyatakan bahwa Earning per Share tidak berpengaruh terhadap harga saham. Demikian pula dengan penelitian Rahma, E.Y. dkk (2014) bahwa Earning per Share berpengaruh positif terhadap Price Earning Ratio. Profitabilitas mempunyai arti penting bagi perusahaan di dalam mempertahankan kelangsungan hidupnya untuk jangka panjang karena seorang investor atau pemegang saham badan usaha berkepentingan atas penghasilan saat ini dan yang diharapkan di masa yang akan datang, kestabilan penghasilan dan keterkaitan dengan penghasilan perusahaan yang lain sehingga investor atau pemegang saham perlu memperhatikan profitabilitas perusahaan. Indikator yang digunakan untuk melihat kemampuan perusahaan memperoleh profitabilitas ini ditunjukkan dari beberapa ratio keuangan antara lain Return on Assets, Return on Equity, Net Profit Margin, dan Earning Per Share. (Husaini, A., 2012)

Return on Asset didefinisikan sebagai ukuran kemampuan perusahaan menghasilkan keuntungan pada masa lampau untuk diproyeksikan di masa yang akan datang (Brigham \& Houston, 2012); (2) Untuk melihat sejah mana investasi yang telah ditanamkan mampu memberikan pengembalian keuntungan sesuai dengan yang diharapkan dari investasi tersebut sebenarnya sama dengan aset perusahaan yang ditanamkan atau ditempatkan (Fahmi, I, 2012:98). ROA dirumuskan sebagai berikut

$$
\begin{aligned}
& \text { Return on Assets }=\frac{\text { Laba Bersih setelah Pajak }}{\text { Total Assets }} \times 100 \% \\
& \text { (Tandelilin, E, 2010) }
\end{aligned}
$$


Semakin besar nilai ROA, menunjukkan kinerja perusahaan yang semakin baik, karena tingkat pengembalian investasi semakin besar. Penelitian Dewi, S.P. \& Hidayat, R. (2014), dan Husaini, A. (2012) menunjukkan Return on Assets memiliki pengaruh terhadap harga saham. Berbeda dengan hasil penelitian Tamuntuan, U. (2015) menyatakan bahwa Return on Assets tidak berpengaruh terhadap harga saham. Penelitian Mandasari, P. (2016) menyatakan bahwa Return on Assets berpengaruh positif terhadap Price Earning Ratio.

Berdasarkan kajian pustaka dan hasil penelitian terdahulu, model penelitian ini ditunjukkan pada Gambar 2.

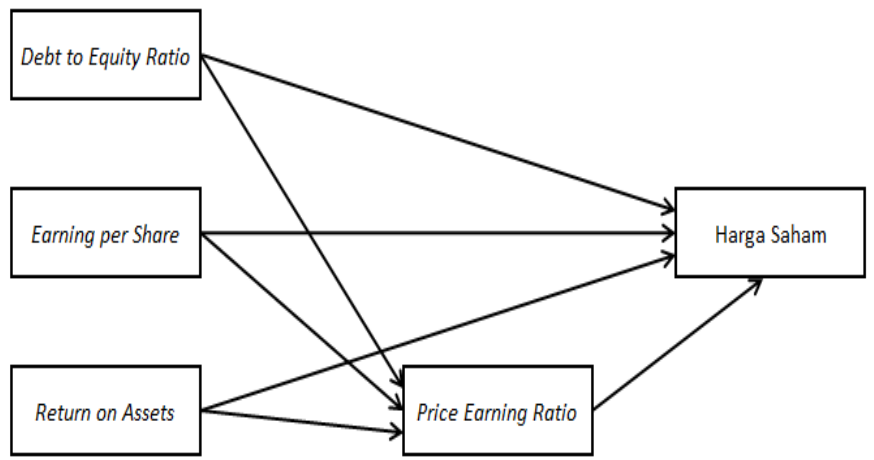

Gambar 2. Model Penelitian

Mengacu pada model penelitian, hipotesis penelitian dirumuskan sebagai berikut:

1. Debt to Equity Ratio berpengaruh terhadap Harga Saham

2. Earning per Share berpengaruh terhadap Harga Saham

3. Return on Assets berpengaruh terhadap Harga Saham

4. Debt to Equity Ratio berpengaruh terhadap Price Earning Ratio

5. Earning per Share berpengaruh terhadap Price Earning Ratio

6. Return on Assets berpengaruh terhadap Price Earning Ratio

7. Price Earning Ratio terhadap Harga Saham

8. Debt to Equity Ratio, Earning per Share, Return on Assets berpengaruh terhadap Price Earning Ratio.

9. Debt to Equity Ratio, Earning per Share, Return on Assets, Price Earning Ratio terhadap Harga Saham

10.Debt to Equity Ratio, Earning per Share, Return on Assets berpengaruh terhadap

Harga Saham melalui Price Earning Ratio

\section{METODE PENELITIAN}

Metode yang digunakan dalam penelitian ini adalah kuantitatif dengan pendekatan deskriptif dan verifikatif. Jenis data merupakan data sekunder bersumber dari laporan keuangan Bursa Efek Indonesia (www.idx.co.id) periode tahun 2013-2017. Populasi adalah perusahaan manufaktur sub sektor rokok yang terdaftar di Bursa Efek Indonesia yang terdiri dari empat perusahaan. Analisis data dilakukan melalui analisis deskriptif dan analisis jalur (Pardede, 2014; Riduwan, 2014). Diagram jalur pada penelitian ini ditunjukan pada Gambar 3.

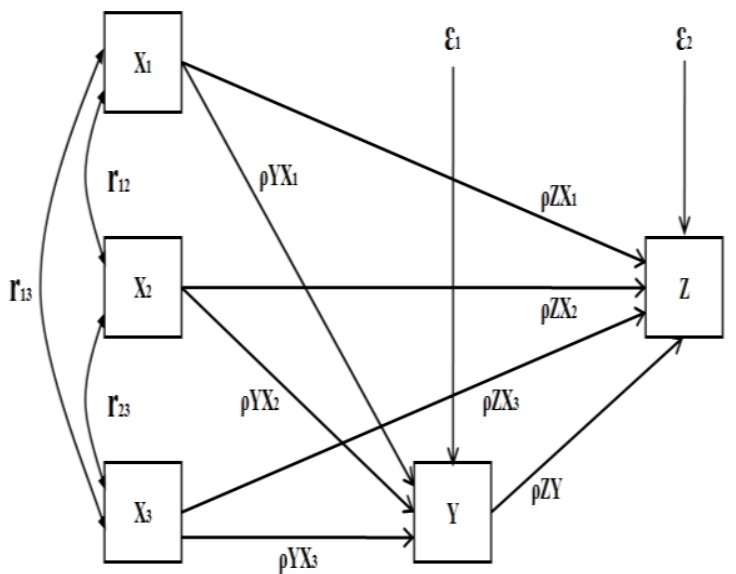

Gambar 3. Diagram Jalur Hubungan Kausal $X_{1}$, $\mathrm{X}_{2}, \mathrm{X}_{3}$ dan $\mathrm{Y}$ ke $\mathrm{Z}$

\section{HASIL DAN PEMBAHASAN}

Analisis deskriptif pada penelitian ini menggunakan nilai minimum, maximum, mean dan standar deviasi, sebagaimana Tabel 2.

Tabel 1. Analisis Deskriptif Descriptive Statistics

\begin{tabular}{|l|r|r|r|r|r|}
\hline & $\mathrm{N}$ & Minimum & Maximum & \multicolumn{1}{c|}{ Mean } & \multicolumn{1}{c|}{$\begin{array}{c}\text { Std. } \\
\text { Deviation }\end{array}$} \\
\hline $\mathrm{HS}$ & 20 & 290.00 & 94000.00 & 27196.4500 & 34234.76429 \\
PER & 20 & -12.80 & 43.42 & 15.7935 & 16.97083 \\
DER & 20 & -8.34 & 9.47 & .2670 & 3.15420 \\
EPS & 20 & -314.74 & 4029.78 & 1130.7495 & 1511.45244 \\
ROA & 20 & -22.23 & 39.48 & 9.3525 & 17.02800 \\
Valid N & 20 & & & & \\
(listwise) & & & & & \\
\hline
\end{tabular}


Tabel 1 menjelaskan harga saham dengan nilai terendah (minimum) diperoleh dari PT Wismilak Inti Makmur Tbk di tahun 2017 terdapat penurunan tingkat konsumsi masyarakat yang dipengaruhi oleh berbagai hal diantaranya kenaikan tarif dasar listrik dan pengalihan subsidi BBM. Kedua indikator tersebut membatasi alokasi belanja masyarakat baik di kelas menengah maupun kelas bawah. Kemudian nilai tertinggi (maximum) diperoleh dari PT Hanjaya Mandala Sampoena Tbk tahun 2015 sebesar 94.000 rupiah. PT Hanjaya Mandala Sampoerna Tbk. mencetak rekor harga saham tertinggi sepanjang sejarah, karena laba meningkat tajam. Nilai rata-rata (mean) sebesar 27.196,45 dengan nilai standar deviasi sebesar 34.234,76 menunjukkan bahwa data tidak terdistribusi dengan baik karena tingkat penyimpangan yang lebih besar dari nilai mean.

Price Earning Ratio (PER) dengan nilai terendah (minimum) diperoleh dari PT Bentoel Internasional Investama Tbk tahun 2017 sebesar -12,80. Saham dibawah nilai PER 10 mencerminkan bahwa saham tersebut undervalue atau investor tidak optimis terhadap kinerja dari perusahaan sehingga dihargai murah. Nilai tertinggi (maximum) diperoleh dari PT Hanjaya Mandala Sampoena Tbk tahun 2017 sebesar 43,42. PER pada emiten HMSP mempunyai nilai PER yang lebih tinggi daripada rata-rata indutrinya (PER perusahaan rokok sebesar 14,39X). Diketahui bahwa pada akhir tahun 2017 harga saham pada emiten HMSP tercatat di 4730 rupiah dengan laba per lembar saham sebesar 108,93 rupiah. Perbandingan tersebut yang menyebabkan nilai PER pada emiten HMSP paling besar diantara emiten lainnya. Nilai rata-rata (mean) sebesar 15,79 berarti Price Earning Ratio (PER) pada perusahaan manufaktur sub sektor rokok memiliki nilai lebih dari 10 yang artinya investor memandang masa depan perekonomian dengan penuh keyakinan. Nilai standar deviasi sebesar 16,97 menunjukkan bahwa data tidak terdistribusi dengan baik karena tingkat penyimpangan yang lebih besar dari nilai mean.

Debt to Equity Ratio dengan nilai terendah (minimum) dan nilai tertinggi (maximum) diperoleh dari PT Bentoel Internasional Investama Tbk tahun 2014 dan
2015. Nilai tersebut berturut-turut sebesar 8,34 dan 9,47. Pada tahun 2014 Liabilitas jangka pendek dan liabilitas jangka panjang per 31 Desember 2014 masing-masing sebesar $\mathrm{Rp} 6$ triliun dan $\mathrm{Rp}$ 5,6 triliun, naik dibandingkan $\mathrm{Rp} 4,7$ triliun dan Rp3,7 triliun per 31 Desember 2013. Kenaikan tersebut disebabkan oleh kenaikan pinjaman dari Grup, yang digunakan untuk terus melanjutkan kegiatan investasi dan mendukung kegiatan operasional. Tahun 2015, total liabilitas per 31 Desember 2015 meningkat 30,7\% menjadi Rp15,8 triliun. Peningkatan ini terutama disebabkan oleh peningkatan pinjaman dari BAT Grup sebesar Rp6,7 triliun untuk mendukung kegiatan investasi dan operasional. Nilai rata-rata (mean) sebesar 0,2670 berarti Debt to Equity Ratio memiliki nilai di bawah 1 atau besaran modal sendiri (equity) lebih besar dibandingkan hutang (liabilities). Nilai standar deviasi sebesar 3,154 menunjukkan bahwa data tidak terdistribusi dengan baik karena tingkat penyimpangan yang lebih besar dari nilai mean.

Earning per Share dengan nilai terendah (minimum) diperoleh dari PT Bentoel Internasional Investama Tbk tahun 2014 sebesar -314,74 rupiah dan nilai tertinggi (maximum) diperoleh dari PT Gudang Garam Tbk tahun 2017 sebesar 4.029,78 rupiah. Nilai rata-rata (mean) 1.130,74 rupiah, berarti EPS yang besar menandakan kemampuan yang lebih besar dalam menghasilkan keuntungan bersih dari setiap lembar saham. Peningkatan EPS menandakan perusahaan berhasil meningkatkan taraf kemakmuran investor, dan hal ini akan mendorong investor untuk menambah jumlah modal yang ditanamkan. Standar deviasi $1.511,45>$ nilai mean. menunjukkan data tidak terdistribusi dengan baik.

Return on Assets dengan nilai terendah (minimum) diperoleh dari PT Bentoel Internasional Investama Tbk tahun 2014 sebesar -22.23. Beban pokok penjualan meningkat $19,8 \%$ menjadi $\mathrm{Rp} 12,6$ triliun, terutama disebabkan oleh kenaikan cukai dan PPN yang dibayarkan pada tahun ini. Ditambah dengan kenaikan harga tembakau, cengkeh dan kenaikan harga input bahan nontembakau akibat dari inflasi yang tinggi dan devaluasi Rupiah. Akibatnya laba kotor 
Perseroan turun $14.8 \%$ menjadi Rp1,5 triliun. Return on Assets dengan nilai terendah (minimum) diperoleh PT Bentoel Internasional Investama Tbk tahun 2014 sebesar -22.23. Beban pokok penjualan meningkat 19,8\% menjadi Rp12,6 triliun, terutama disebabkan oleh kenaikan cukai dan PPN yang dibayarkan pada tahun ini. Ditambah dengan kenaikan harga tembakau, cengkeh dan kenaikan harga input bahan nontembakau akibat dari inflasi yang tinggi dan devaluasi Rupiah. Akibatnya laba kotor Perseroan turun $14.8 \%$ menjadi Rp1,5 triliun. Nilai rata-rata (mean) 9,35 dengan nilai standar deviasi 17,02 menunjukkan bahwa data tidak terdistribusi dengan baik karena tingkat penyimpangan yang lebih besar dari nilai mean.

Sebelum dilakukan analisis, dilakukan uji asumsi klasik meliputi uji normalitas, multikoliniearitas, heteroskedastisitas, dan autokorelasi. Hasil Uji normalitas pada Tabel 2 menunjukkan nilai Sig. 0,993>0,05 dimaknai data berdistribusi normal. Selanjutnya uji multikolinieritas pada Tabel 3 menunjukkan nilai tolerance untuk semua variabel memiliki nilai tolerance $>0.1$ dan nilai VIF $<10$ yang dimaknai tidak terdapat gejala multikolinearitas. Uji Autokorelasi pada Tabel 4 diperoleh nilai Durbin-Watson sebesar 1,625. Nilai tesebut berada di antara -2 sampai +2 , maka dapat disimpulkan bahwa pada model tidak terjadi autokorelasi

Tabel 2. One-Sample Kolmogorov-Smirnov Test

\begin{tabular}{|ll|r|}
\hline & & $\begin{array}{c}\text { Unstandardized } \\
\text { Residual }\end{array}$ \\
\hline $\mathrm{N}$ & & 20 \\
Normal & Mean & .0000000 \\
Parameters & a,b & Std. Deviation \\
Most & Absolute & 6.74782581 \\
Extreme & Positive & .096 \\
Differences & Negative & .046 \\
Kolmogorov-Smirnov Z & -.096 \\
Asymp. Sig. (2-tailed) & .431 \\
\hline
\end{tabular}

a. Test distribution is Normal.

Tabel 3. Hasil Uji Multikolinearitas

\begin{tabular}{|c|c|c|c|c|c|c|c|}
\hline & & & Coefficients $^{8}$ & & & & \\
\hline \multirow[t]{2}{*}{ Model } & \multicolumn{2}{|c|}{$\begin{array}{l}\text { Unstandardized } \\
\text { Coefficients }\end{array}$} & $\begin{array}{c}\text { Standardized } \\
\text { Coefficients }\end{array}$ & \multirow[t]{2}{*}{$t$} & \multirow[t]{2}{*}{ Sig. } & \multicolumn{2}{|c|}{$\begin{array}{c}\text { Collinearity } \\
\text { Statistics }\end{array}$} \\
\hline & $B$ & Std. Error & Beta & & & Tolerance & VIF \\
\hline (Constant) & 6.282 & 2.117 & & 2.968 & .009 & & \\
\hline DER & .745 & .550 & -138 & 1354 & 194 & 946 & 1.057 \\
\hline EPS & .001 & .001 & .117 & 1.056 & .307 & .807 & 1.239 \\
\hline ROA & .880 & .112 & .883 & 7.837 & .000 & .779 & 1.284 \\
\hline
\end{tabular}

.Tabel 4. Hasil Uji Autokorelasi

\begin{tabular}{|l|r|r|r|r|r|}
\hline Model & R & R Square & $\begin{array}{c}\text { Adj R } \\
\text { Square }\end{array}$ & $\begin{array}{r}\text { Std. Error of } \\
\text { the Estimate }\end{array}$ & $\begin{array}{r}\text { Durbin- } \\
\text { Watson }\end{array}$ \\
\hline 1 & $.918^{\mathrm{a}}$ & .842 & .812 & 7.35327 & 1.625 \\
\hline
\end{tabular}
a. Predictors: (Constant), ROA, DER, EPS
b. Dependent Variable: PER

Uji Heteroskedastisitas pada Gambar 3 menunjukkan titik-titik menyebar di atas dan di bawah angka nol pada sumbu Y serta tidak membentuk pola tertentu yang teratur, sehingga tidak terjadi masalah heteroskedastisitas

(variance sama/Homoskedastisitas).

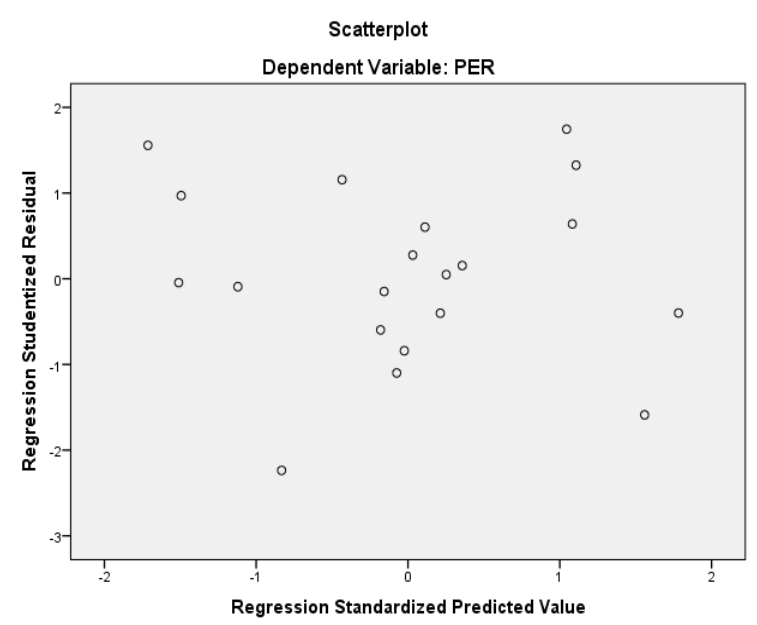

Gambar 3. Uji Heteroskedastisitas

Pengaruh langsung dan tidak langsung variabel Debt to Equity Ratio (DER), Earning Per Share (EPS), Return on Assets (ROA), terhadap Harga Saham (HS) dengan Price Earning Ratio (PER) sebagai variabel intervening, dinyatakan pada Gambar 4.

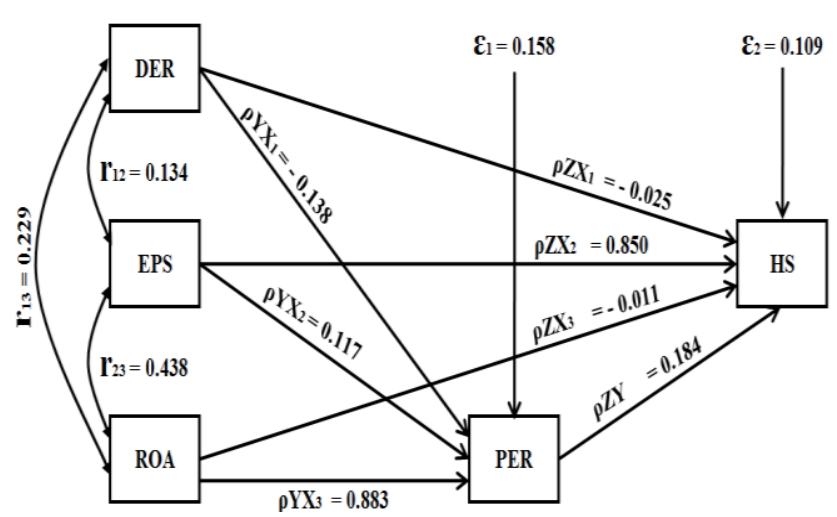

Gambar 4. Model Diagram Jalur 
Gambar 4 menjelaskan bahwa: (1) Pengaruh Debt to Equity Ratio (DER) terhadap Price Earning Ratio (PER) sebesar $-0,138^{2}=$ 0,019 atau $1,90 \%$ dengan signifikansi $0,194>$ 0.05, dimaknai tidak terdapat pengaruh signifikan DER terhadap PER. Temuan ini selaras dengan penelitian Rhidho, R. \& Prabawa, S.A (2012); Arisona, V.F. (2013) yang menjelaskan bahwa Debt to Equity Ratio tidak berpengaruh signifikan terhadap Price Earning Ratio. (2) Pengaruh Earning per Share (EPS) terhadap Price Earning Ratio (PER) sebesar $0,117^{2}=0,0137$ atau $1,37 \%$ dengan signifikansi 0,307 >0.05, dimaknai tidak terdapat pengaruh signifikan EPS terhadap PER. (3) Pengaruh Return on Assets (ROA) terhadap PER sebesar $0,883^{2}=0,7797$ atau $77,97 \%$ dengan signifikansi $0,000<0.05$, dimaknai terdapat pengaruh signifikan ROA terhadap PER. Temuan ini selaras dengan penelitian Mandasari, P. (2016) bahwa Return on Assets berpengaruh positif terhadap Price Earning Ratio. (4) Pengaruh langsung Debt to Equity Ratio (DER) terhadap Harga Saham (HS) sebesar $-0,025^{2}=0,0006$ atau $0,06 \%$, dengan signifikansi $0,793>0.05$, dimaknai tidak terdapat pengaruh signifikan DER terhadap Harga Saham. Temuan ini selaras penelitian Safitri, A.L. (2013), Nurfadillah, M. (2011), Iqbal, A. dkk (2016) bahwa Debt to Equity Ratio tidak berpengaruh terhadap Harga Saham. (5) Pengaruh langsung Earning per Share (EPS) terhadap Harga Saham (HS) sebesar $0,850^{2}=0,7225$ atau $72,25 \%$ dengan signifikansi $0,000<0.05$, dimaknai terdapat pengaruh signifikan EPS terhadap Harga Saham (HS).

Temuan ini selaras dengan penelitian Husaini, A. (2012), Tamuntuan, U. (2015) dan Ratih, D. dkk (2013) bahwa Earning per Share berpengaruh terhadap harga saham (6) Pengaruh langsung Return on Assets (ROA) terhadap Harga Saham (HS) sebesar $-0,011^{2}=$ 0,001 atau $0,01 \%$ dengan signifikansi $0,961>$ 0.05, dimaknai tidak terdapat pengaruh signifikan ROA terhadap Harga Saham (HS).

Pengaruh langsung Price Earning Ratio (PER) terhadap Harga Saham (HS) sebesar $0,184^{2}=0,0339$ atau 3,39\% dengan signifikansi $0,404>0.05$, dimaknai tidak terdapat pengaruh signifikan PER terhadap Harga Saham (HS). Temuan ini selaras dengan penelitian Amanda, A. dkk (2012) bahwa Price Earning Ratio tidak berpengaruh terhadap harga saham. (8) Pengaruh total DER terhadap Harga Saham melalui PER sebesar -0,05 atau 5\%, dengan pengaruh signifikan; (9) Pengaruh total EPS terhadap Harga Saham melalui PER sebesar 0,872 atau 87,2\% dengan pengaruh signifikan; (10) Pengaruh ROA terhadap Harga Saham sebesar 0,152 atau $15.2 \%$ dengan pengaruh signifikan.

\section{KESIMPULAN DAN SARAN}

Simpulan dari penelitian ini bahwa: (1) Debt to Equity Ratio tidak berpengaruh signifikan terhadap Price Earning Ratio; (2) Earning per Share tidak memberikan pengaruh secara signifikan terhadap Price Earning Ratio; (3) Return on Assets memberikan pengaruh signifikan terhadap Price Earning Ratio; (4) Debt to Equity Ratio tidak berpengaruh signifikan terhadap Harga Saham; (5) Earning per Share memberikan pengaruh signifikan terhadap Harga; (6) Return on Assets tidak memberikan pengaruh signifikan terhadap Harga Saham; (7) Price Earning Ratio tidak berpengaruh signifikan terhadap Harga Saham; (8) Debt to Equity Ratio, Earning per Share, dan Return on Assets secara simultan berpengaruh signifikan terhadap Price Earning Ratio; (9) Debt to Equity Ratio, Earning per Share, Return on Assets dan Price Earning Ratio secara simultan berpengaruh signifikan terhadap Harga Saham; (10) Debt to Equity Ratio, Earning per Share dan Return on Assets secara simultan berpengaruh signifikan terhadap Price Earning Ratio

Mengacu pada simpulan, saran yang dapat diajukan (1) Untuk mencapai Return on Asset yang diharapkan, perusahaan harus menjaga kemampuan perusahaan dalam mengalokasikan dana pada berbagai investasi yang lebih menguntungkan; (2) Perusahaan terus berupaya meningkatkan profitabilitas melalui peningkatan total asset yang dimiliki dan jumlah saham yang beredar, agar pertumbuhan aset terus meningkat, kelangsungan hidup perusahaan terjaga serta kepercayaan investor meningkat; (3) Penelitian ini terbatas pada 4 variabel, peneliti selanjutnya sebaiknya menambah variabel lain yang mungkin lebih dominan mempengaruhi 
harga saham. Selain itu sebaiknya agar memperpanjang periode penelitian serta menggunakan model analisis data yang berbeda agar hasil penelitian lebih tepat dan akurat serta bisa mewakili fakta yang terjadi di lapangan.

\section{DAFTAR PUSTAKA}

Amanda, A., dkk (2012). Pengaruh DER, ROE, EPS dan PER terhadap Harga Saham.

Anoraga, P. \& Pakarta, P. (2008). Pengantar Pasar Modal, Cetakan Ketiga. Rineka Cipta. Semarang.

Arisona, V.F. (2013). Faktor-Faktor yang Mempengaruhi Price Earning Ratio. Jurnal Ilmu Manajemen. 1 (1).

Brigham \& Houston. (2010). Dasar-Dasar Manajemen Keuangan Buku 1. Edisi Kesebeles. Jakarta: Salemba Empat.

Brigham \& Houston. (2011). Dasar-dasar Manajemen Keuangan Terjemahan. Edisi 10. Salemba Empat. Jakarta.

Dewi, S.P. \& Hidayat, R. (2014), Pengaruh NPM dan ROA terhadp Harga Saham pada Perusahaan Otomotif yang terdaftar di Bursa Efek Indonesia. ILMAN 1 (1), 1-10.

Febrianto, A.D., \& Kartawinata, B.D. (2014), Pengaruh DPS dan EPS terhadap Harga Saham Sektor Pertambangan Sub Sektor Batu Bara di Bursa Efek Indonesia Periode 2009-2013. $e$ Proceeding of Management. 2 (2), 1924-1931.

Fahmi, I. (2012). Analisis Laporan Keuangan. Cetakan ke-2. Alfabeta .Bandung.

Fahmi, I. (2013). Analisis Laporan Keuangan. Alfabeta. Bandung.

Jogiyanto. (2013). Metodologi Penelitian Bisnis: Salah Kaprah dan Pengalaman- Pengalaman. Edisi Keenam. BPFE Yogyakarta.

Husaini, A. (2012). Pengaruh Variabel ROA, ROE, NPM dan EPS terhadap Harga Saham Perusahaan. Jurnal Profit. 6 (1).

http://britama.com/index.php/2013/03/sejarahdan-profil-singkat-wiim/

Iqbal, A. dkk. (2016). Impact of Leverages on Sgare Price: Evidance from Cement
Sector of Pakistan. Industrial Engineering Letters ISSN 22246096 (Paper) ISSN 2225-0581 (online). $6(6)$.

Kasmir. (2012). Bank dan Lembaga Kuangan Lainnya. PT. Raja Grafindo Persada. Jakarta.

Kasmir, (2014). Analisis Laporan Keuangan, Edisi Pertama, Cetakan Ketujuh. PT. Rajagrafindo Persada. Jakarta.

Mandasari, P. (2016), Pengaruh DPR, DER, Dan ROA terhadap PER pada Perusahaan Sektor Barang Konsumsi yang Terdaftar di BEI. Jurnal Profita. Edisi 7.

Mujati, Y. \& Dzulqodah, M. (2016). Pengaruh EPS dan PER terhadap DER dan Harga Saham pada Perusahaan Sektor Makanan dan Minuman di BEI. EKSIS. 9 (1).

Nurfadillah, M. (2011). Analisis Pengaruh EPS, DER dan ROE terhadap Harga Saham PT. Unilever Indonesi4a Tbk. Jurnal Manajemen dan Akuntansi. 12(1).

Pardede, R. (2014). Analisis Jalur-Path Analysis: Teori dan aplikasi dalam riset bisnis. Rineka Cipta. Jakarta.

Rachmat, M. \& Nuryanti, S. (2009). Dinamika Agribisnis Tembakau Dunia dan Implikasinya Bagi Indonesia. Forum Penelitian Agro Ekonomi 27 (2) , 7391. Bogor : Pusat Analisis Sosial Ekonomi dan Kebijakan Pertanian

Rahma, E. Y., dkk. (2014). Analisis Variabel Fundamental yang berpengaruh terhadap Price Earning Ratio sebagai Dasar Penilaian Saham pada Perusahaan Automotive and Allied yang terdaftar di Bursa Efek Indonesia. Jurnal Aplikasi Manajemen. 12 (3), 28-38.

Ratih, D., dkk (2013). Pengaruh EPS, PER, DER, ROE terhadap Harga Saham pada Perusahaan Sektor Pertambangan yang terdaftar di Bursa Efek Indonesia Tahun 2010-2012. Dipenogoro Journal of Social anda Politic. 1-12.

Ridho, R., \& Prabawa., S.A. (2012). FaktorFaktor Yang Mempengaruhi Price Earning Ratio Saham Perusahaan 
Manufaktur. Jurnal Ilmiah Manajemen. $7(1)$.

Riduwan \& Kuncoro, E.A. (2014). Cara Menggunakan dan Memaknai Path Analysis. Alfabeta. Bandung.

Rusdin. (2008). Pasar Modal Cetakan Kedua. Alfabeta. Bandung.

Safitri, A.L. (2013). Pengaruh EPS, PER, ROA, DER, da MVA terhadap Harga Saham dalam Kelompok Jakarta Islami Index. Management Analysis Journal, $2(2)$.

Sartono, A. (2010). Manajemen Keuangan Teori dan Aplikasi Edisi Empat. BPFE.Yogyakarta.

Sinaga, B. (2014). Main Saham Pakai Liat. Cetakan pertama. Gramedia Pressindo. Jakarta.

Tamuntuan, U. (2015). Analysing The Effect Of Return On Equity, Return On Assets And Earnings Per Share Toward Share Price: An Emperical Study Of Food And Beverage Companies Listed On Indonesia Stock Exchange. Jurnal Berkala Ilmiah Efisiensi, 5 (5).

Tandelilin, E. (2010). Portofolio dan Investasi Teori dan Aplikasi. Edisi Pertama. Kanisius. Yogyakarta .

Zuliarni, S. (2012). Pengaruh Kinerja Keuangan terhadap Harga Saham pada Perusahaan Minin and Mining Service di Bursa Efek Indonesia. Jurnal Aplikasi Bisnis, 3 (1).

Widoatmodjo, S. (2012). Cara Cepat Memulai Investasi Saham Panduan Bagi Pemula. PT Elex Media Komputindo. Jakarta.

Widiyanto, J. (2012). SPSS for Windows. Surakarta: Badan Penerbit -FKIP Universitas Muhammadiyah Surakarta. 
Journal IMAGE | Volume 7, Number 2, November 2018, page 59-68 
Journal IMAGE | Volume 7, Number 2, November 2018, page 59-68 
Journal IMAGE | Volume 7, Number 2, November 2018, page 59-68 